\title{
Hurthle Cell Metaplasia of Thyroid Gland
}

National Cancer Institute

\section{Source}

National Cancer Institute. Hurthle Cell Metaplasia of Thyroid Gland. NCI Thesaurus. Code C7763.

A morphologic finding indicating transformation of follicular cells to large cells with abundant eosinophilic and granular cytoplasm (Hurthle cells) in the thyroid gland. 